\title{
IMPLEMENTASI MODEL PEMBELAJARAN CTL (CONTEXTUAL TEACHING AND LEARNING) DALAM PEMBELAJARAN BAHASA INDONESIA DI SEKOLAH DASAR
}

\author{
Oleh \\ Ni Made Sitiasih \\ madesitiasih@gmail.com \\ SD Negeri 2 Peguyangan, Bali, Indonesia
}

diterima 10 Agustus 2019, direvisi 17 September 2019, diterbitkan 1 Oktober 2019

\begin{abstract}
ABSTRAK
Penelitian ini dilaksanakan di SD Negeri 2 Peguyangan di Kelas III semester II Tahun Pelajaran 2017/2018 dengan tujuan untuk mengetahui apakah Penggunaan model pembelajaran CTL (Contextual Teaching And Learning) dapat meningkatkan prestasi belajar Bahasa Indonesia siswa kelas III semester II tahun Pelajaran 2017/2018. Metode pengumpulan datanya adalah tes prestasi belajar dengan metode analisis datanya adalah deskriptif kuantitatif karena data yang diperoleh masih berbentuk angka. Hasil yang diperoleh dari penelitian ini dapat dijabarkan sebagai berikut: untuk data awal 63,5 data siklus I terjadi peningkatan 66,73 dan pada siklus II meningkat menjadi 80,19. Setelah dilakukan analisis dari data yang ada maka diperoleh kesimpulan Penggunaan model pembelajaran CTL( Contextual Teaching And Learning) jika dilaksanakan dapat meningkatkan prestasi belajar siswa.
\end{abstract}

Kata kunci: Contextual Teaching And Learning ,Prestasi belajar, bahasa Indonesia

\section{Pendahuluan}

Guru sebagai ujung tombak pelaksana dalam proses pembelajaran dituntut untuk lebih kreatif dan inovatif dalam menjalankan UU dimaksud. Kreatif dalam mencari pengetahuan dan pemahaman berharga sebagai bekal dalam menjalankan tugas pembelajaran yang inovatif dan profesional demi peningkatan kualitas pendidikan dalam rangka mencerdaskan generasi muda penerus estafet kepemimpinan bangsa. Dari pengamatan awal, prestasi belajar siswa pada mata pelajaran bhaas Indonesia baru mencapai nilai rata-rata 65,7 Hasil ini sangat jauh dari di bawah nilai rata-rata KKM yang ditetapkan di sekolah ini.

$$
\text { Keberhasilan proses }
$$

pembelajaran tentunya banyak ditentukan oleh pemanfaatan metode dan strategi belajar yang efektif. Salah satu strategi pembelajaran yang dikembangkan dengan tujuan agar pembelajaran berjalan dengan produktif dan bermakna bagi siswa adalah strategi pembelajaran kontekstual (Contextual Teaching and Learning) yang selanjutnya 
ADI WIDYA: Jurnal Pendidikan Dasar

FAKULTAS DHARMA ACARYA

INSTITUT HINDU DHARMA NEGERI DENPASAR
Volume. 4, Nomor 2 Oktober 2019

ISSN: 2685-8312 (online)

ISSN: 2527-5445 (cetak

http://ejournal.ihdn.ac.id/index.php/AW disebut CTL. Strategi CTL fokus pada siswa sebagai pembelajar yang aktif, dan memberikan rentang yang luas tentang peluang-peluang belajar bagi mereka yang menggunakan kemampuan-kemampuan akademik mereka untuk memecahkan masalahmasalah kehidupan nyata yang kompleks. Dengan konsep dasar pemahaman model pembelajaranContextual Teaching And Learning(CTL),peneliti yakin mampu membantu siswa untuk memahami materi ajar dan mengaitkannya konsep-konsep dasar yang diterima untuk dimanfaatkan dinamis dan fleksibel sebagai acuan memecahkan masalah dalam kehidupan sehari-hari (konteks pribadi, sosial dan kultur). Menurut Wina Sanjaya (2005: 109) bahwa CTL adalah suatu pendekatan pembelajaran yang menekankan pada proses keterlibatan siswa secara penuh untuk dapat menemukan materi yang dipelajari dan menghubungkannya dengan situasi kehidupan nyata sehingga mendorong siswa untuk dapat menerapkannya dalam kehidupan mereka.

Pembelajaran CTL seperti yang dijelaskan Hajir dimulai dengan sajian atau tanya jawab lisan (ramah, terbuka, negosiasi) yang terkait dengan dunia nyata kehidupan siswa (sehingga akan terasa manfaat dari materi yang akan disajkan, motivasi belajar muncul, dunia pikiran siswa menjadi konkret, dan suasana menjadi kondusif - nyaman dan menyenangkan. Prinsip pembelajaran CTL adalah aktivitas siswa, siswa melakukan dan mengalami, tidak hanya menonton dan mencatat, dan pengembangan kemampuan sosialisasi. Upaya yang ditetapkan tersebut, merupakan cara terbaik yang dapat digunakan sebagai dasar pemecahan masalah yang ada. Dalam penelitian ini, sehubungan dengan permasalahan yang telah disampaikan, tujuan dapat disampaikan sebagai berikut: Untuk mengetahui seberapa tinggi peningkatan prestasi belajar bahasa Indonesia siswa kelas III semester II SD Negeri 2 Peguyangan tahun pelajaran 2017//2018 akan terjadi setelah diterapkan model pembelajaran (CTL ) Contextual Teaching And Learning..

\section{Metode}

Penelitian ini dilaksanakan di SD Negeri 2 Peguyangan dengan jenis penelitian berupa penelitian tindakan kelas. Dalam Penelitian Tindakan rancangan didesain dalam bentuk siklus dengan pemberian tindakan. Penelitian ini akan dilaksanakan dalam dua siklus yang setiap siklusnya terdiri dari tiga kali pertemuan untuk memberikan tindakan. Tahap pertama disebut tahap perencanaan, rancangan dilakukan bersama antara peneliti yang akan melakukan tindakan dengan guru lain yang akan mengamati proses jalannya tindakan. Hal tersebut untuk mengurangi unsur subjektivitas pengamat serta mutu kecermatan pengamatan yang dilakukan. Tahap kedua adalah tahap pelaksanaan tindakan dilakukan dengan pembelajaran di kelas. Pada tahap ini guru peneliti giat melakukan tindakan menggunakan medel CTL Rancangan tindakan tersebut sebelumnya telah dilatih 
untuk dapat diterapkan di dalam kelas sesuai dengan skenarionya. Skenario dari tindakan diupayakan dilaksanakan dengan baik dan wajar. Tahap ketiga adalah tahap pengamatan, Pengamatan dilakukan pada waktu tindakan sedang berjalan, jadi, keduanya berlangsung dalam waktu yang sama. Pada tahap ini, guru yang bertindak sebagai peneliti melakukan pengamatan dan mencatat semua hal yang diperlukan dan terjadi selama pelaksanaan tindakan berlangsung. Pengumpulan data ini dilakukan dengan menggunakan tes prestasi belajar yang telah tersusun, termasuk juga pengmatan secara cermat pelaksanaan skenario tindakan dari waktu ke waktu serta dampaknya terhadap proses dan hasil belajar siswa.

\section{III.Hasil Penelitian}

dan

\section{Pembahasan}

\section{A. Hasil Penelitian}

1. Siklus I

\section{Refleksi Siklus I}

Analisis kuantitatif Prestasi belajar siswa siklus I

a. Rata-rata (mean) dihitung dengan: $\frac{\text { Jumlah nilai }}{\text { Jumlah siswa }}=\frac{2495}{37}=67,43$

b. Tabel 05. Data Kelas Interval Median (titik tengahnya) dicari dengan mengurut data/nilai siswa dari yang terkecil sampai terbesar. Setelah diurut apabila jumlah data ganjil maka mediannya adalah data yang ditengah. Kalau jumlahnya genap maka dua data yang di tengah dijumlahkan dibagi 2 (dua). Untuk median yang diperoleh dari data

$$
\text { Data hasil penelitian }
$$
dikumpulkan melalui observasi dan tes prestasi belajar.Tes dilakukan berdasarkan tujuan pembelajaran yang akan dicapai guna mengukur hasil belajar siswa. Data hasil penelitian ini dianalisis menggunakan metode deskriptif. Untuk data kuantitatif dianalisis dengan mencari mean, median, modus, membuat interval kelas dan melakukan penyajian dalam bentuk tabel dan grafik. Dalam penelitian ini diusulkan tingkat keberhasilan per siklus yaitu pada siklus I prestasi belajar siswa mencapai nilai ratarata. 66,73 dengan ketuntasan belajar sebesar $65,0 \%$ dan pada siklus II mencapai nilai rata-rata 80,19 atau lebih dengan ketuntasan belajar minimal $80 \%$

siklus I dengan menggunakan cara tersebut adalah: 70

c. Modus (angka yang paling banyak/paling sering muncul) setelah diasccending/diurut angka tersebut adalah: 70

d. Untuk persiapan penyajian dalam bentuk grafik maka hal-hal berikut dihitung terlebih dahulu.

1. Banyak kelas $(\mathrm{K})=1+3,3 \times \log$ (N)

$$
\begin{aligned}
& =1+3,3 \times \log 37 \\
& =1+3,3 \times 1,6 \\
& =1+5,28=6,28 \rightarrow 6
\end{aligned}
$$

2. Rentang kelas (r) $=$ skor maksimum - skor minimum

$=80-55$ $=25$

3. Panjang kelas interval (i) = $\frac{r}{K}=\frac{25}{6}=4,16 \rightarrow 4$ 
4. Siklus I

\begin{tabular}{|c|c|c|c|c|}
\hline $\begin{array}{l}\text { No } \\
\text { Urut }\end{array}$ & Interval & $\begin{array}{c}\text { Nilai } \\
\text { Tengah }\end{array}$ & $\begin{array}{c}\text { Frekuensi } \\
\text { Absolut }\end{array}$ & $\begin{array}{c}\text { Frekuensi } \\
\text { Relatif }\end{array}$ \\
\hline 1 & $55-58$ & 56,5 & 4 & 10,81 \\
\hline 2 & $59-62$ & 60,5 & 10 & 27,03 \\
\hline 3 & $63-66$ & 64,5 & 0 & 0,00 \\
\hline 4 & $67-70$ & 68,5 & 14 & 37,84 \\
\hline 5 & $71-74$ & 72,5 & 0 & 0,00 \\
\hline 6 & $75-78$ & 76,5 & 5 & 13,51 \\
\hline 7 & 79- 82 & 80,5 & 4 & 10,81 \\
\hline \multicolumn{3}{|c|}{ Total } & 37 & 100 \\
\hline
\end{tabular}

\section{Siklus II}

\section{Refleksi Siklus II}

a. Analisis

kuantitatif

Prestasi belajar siswa siklus II

1. Rata-rata (mean) dihitung dengan:

$\frac{\text { Jumlah nilai }}{\text { Jumlah siswa }}=\frac{2915}{37}=78,78$

2. Median (titik tengahnya) dicari dengan mengurut data/nilai siswa dari yang terkecil sampai terbesar. Setelah diurut apabila jumlah data ganjil maka mediannya adalah data yang ditengah. Kalau jumlahnya genap maka dua data yang di tengah dijumlahkan dibagi 2 (dua). Untuk median yang diperoleh dari data siklus I dengan menggunakan cara tersebut adalah: 75

3. Modus (angka yang paling banyak/paling sering muncul) setelah diasccending/diurut. Angka tersebut adalah: 70 dan 90

4. Untuk persiapan penyajian dalam bentuk grafik maka halhal berikut dihitung terlebih dahulu.

1. Banyak kelas $(\mathrm{K})=1+3,3 \mathrm{x}$ $\log (\mathrm{N})$

$=1+3,3 \times \log 37$

$=1+3,3 \times 1,6$

$=1+5,28=6,28 \rightarrow 6$

2. Rentang kelas (r) $=$ skor maksimum - skor minimum

$=90-65$

$=25$

3. Panjang kelas interval (i) $=$ $\frac{r}{K}=\frac{25}{6}=4,16 \rightarrow 4$ 
ADI WIDYA: Jurnal Pendidikan Dasar

FAKULTAS DHARMA ACARYA

INSTITUT HINDU DHARMA NEGERI DENPASAR
Volume. 4, Nomor 2 Oktober 2019

ISSN: 2685-8312 (online)

ISSN: 2527-5445 (cetak

http://ejournal.ihdn.ac.id/index.php/AW

Tabel 05. Data Kelas Interval Siklus II

\begin{tabular}{|c|c|c|c|c|}
\hline $\begin{array}{l}\text { No } \\
\text { Urut }\end{array}$ & Interval & $\begin{array}{c}\text { Nilai } \\
\text { Tengah }\end{array}$ & $\begin{array}{c}\text { Frekuensi } \\
\text { Absolut }\end{array}$ & $\begin{array}{c}\text { Frekuensi } \\
\text { Relatif }\end{array}$ \\
\hline & $65-68$ & 66,5 & 1 & 2,70 \\
\hline 1 & $69-72$ & 70,5 & 12 & 32,43 \\
\hline 2 & $73-76$ & 74,5 & 6 & 16,22 \\
\hline 3 & $77-80$ & 78,5 & 6 & 16,22 \\
\hline 4 & $81-84$ & 82,5 & 0 & 0,00 \\
\hline 5 & $85-88$ & 86,5 & 0 & 0,00 \\
\hline 6 & $89-92$ & 90,5 & 12 & 32,43 \\
\hline \multicolumn{3}{|c|}{ Total } & 37 & 100 \\
\hline
\end{tabular}

\section{B. Pembahasan}

Data awal yang diperoleh dengan rata-rata 63,50 menunjukkan bahwa kemampuan anak/siswa dalam mata pelajaran Bahasa Indonesia masih sangat rendah mengingat kriteria ketuntasan belajar siswa untuk mata pelajaran ini di SD Negeri 2 Peguyangan adalah 70,00 .Dengan nilai yang sangat rendah seperti itu maka peneliti mengupayakan untuk dapat meningkatkan prestasi belajar Bahasa Indonesia siswa kelas III semester II tahun Pelajaran 2017/2018. Akhirnya dengan Penggunakan model pembelajaran CTL (Contextual Teaching and Learning ) yang benar sesuai teori yang ada, peningkatan rata-rata prestasi belajar siswa pada siklus I dapat diupayakan dan mencapai ratarata. 70 Namun rata-rata baru mancapai 67,43 hal tersebut belum maksimal karena hanya23 siswa memperoleh nilai di atas KKM sedangkan yang lainnya belum mencapai KKM. Sedangkan prosentase ketuntasan belajar mereka baru mencapai $62,16 \%$ Hal tersebut terjadi akibat penggunaan model CTL belum maksimal dapat dilakukan disebabkan penerapan model tersebut baru dicobakan sehingga guru masih belum mampu melaksanakannya sesua alur teori yang benar.

Pada siklus ke II perbaikan prestasi belajar siswa diupayakan lebih maksimal dengan peneliti membuat perencanaan yang lebih baik, menggunakan alur dan teori dari model CTL dengan benar dan lebih maksimal. Peneliti giat memotivasi siswa agar giat belajar, memberi arahan-arahan, menuntun mereka untuk mampu menguasai materi pelajaran pada mata pelajaran Bahasa Indonesia lebih optimal. Akhirnya dengan semua upaya tersebut peneliti mampu meningkatkan prestasi belajar siswa pada siklus II menjadi rata-rata 78,78 Upaya-upaya yang maksimal tersebut menuntun kepada penelitian bahwa model CTL mampu meningkatkan prestasi belajar bahasa Indonesia siswa Kelas III semester II SD Negeri 2 Peguyangan tahun pelajaran 2017/2018.

\section{Simpulan}

Semua hasil analisis data yang telah dilakukan pada siswa 
kelas III semester II SD Negeri 2 Peguyangan menyangkut rendahnya prestasi belajar Bahasa Indonesia yang diupayakan perbaikannya melalui penerapan model pembelajaran CTL, maka kesimpulan yang diperoleh dijelaskan sebagai berikut:

Data awal yang diperoleh menunjukkan bahwa hanya 17 siswa yang mendapat nilai dibawah KKM dan setelah dilakukan tindakan dalam tiga kali pertemuan pada siklus I menurun menjadi 14 siswa dan siklus II hanya 1 siswa mendapat nilai di bawah KKM. Dari rata-rata awal rata-rata 63,50 setelah diberikan tindakan pada siklus I naik menjadi 67,43 dan pada siklus II meningkat menjadi 78,78

Dari data awal siswa yang tuntas hanya 20 orang sedangkan pada siklus I setelah dilakukan tindakan dengan penerapan pembelajaran CTL ketuntasan belajar siswa meningkat menjadi 23 orang dan pada siklus II meningkat menjadi 36 siswa.

Dari data tersebut diatas maka dapat dimpulkan adalah Penggunaan Model Pembelajaran CTL( Contextual Teaching And Learning ) dapat meningkatkan prestasi belajar bahasa Indonesia Siswa kelas III Semester II SD Negeri 2 Peguyangan Tahun pelajaran 2017/2018.

\section{DAFTAR PUSTAKA}

Arikunto, Suharsimi; Suhardjono; Supardi. 2006. Penelitian Tindakan Kelas. Jakarta: PT Bumi Aksara.

Depdiknas. Direktorat Tenaga Kependidikan, Direktorat Jendral Peningkatan Mutu Pendidik 2002. Contextual Teaching And Learning. Jakarta: Dirjen Pendidikan Dasar dan Menengah..

Dimyati dan Mudjiono. 2001. Belajar dan Pembelajaran. Jakarta: Dirjen Dikti.

Djamarah, Syaful Bahri. 2002. Prestasi Belajar dan Kompetensi Guru. Surabaya: Usaha Nasional.

Irianto, Agus. 1989. Bahan Ajaran Statistika Pendidikan (Buku Kedua). Jakarta: Proyek Pengembangan Lembaga Pendidikan Tenaga Kependidikan

Purwanto, Ngalim. 1997. Psikologi Pendidikan. Bandung: Rosdakarya.

Suryabrata, Sumadi. 2000. Pengembangan Alat Ukur Psikologis. Yogyakarta: Penerbit Andi.

Surya, Mohammad. 2004. Psikologi Pembelajaran dan Pengajaran. Bandung: Pustaka Bani Quraisy.

Wina Sanjaya. 2005. Pembelajaran dalam implementasi kurikulum berbasis kompetensi. Jakarta: Kencana prenada media group 